\title{
Life cycle of the fish parasite Gnathia maxillaris (Crustacea: Isopoda: Gnathiidae)
}

\author{
Coral Hispano $^{1}$, Patrici Bultó ${ }^{1}$ and Anicet R. Blanch ${ }^{2}$ \\ ${ }^{1}$ L'Aquàrium, Moll d'Espanya del Port Vell, Barcelona, Spain; \\ ${ }^{2}$ Department of Microbiology, University of Barcelona, Barcelona, Spain
}

\begin{abstract}
The taxonomic classification of some parasitic isopods of the family Gnathiidae has been revised in the last years. However, their biological cycles have been described only partially or incompletely. Gnathia maxillaris (Montagu, 1804) is one of the most studied species, but certain aspects of its life cycle are still poorly known. A detailed study on the life cycle of G. maxillaris was carried out over several years by sampling larvae from an infestation of large volume aquaria at the Aquarium of Barcelona. At the same time, a system of in vitro cultivation of G. maxillaris was developed, which provided new data to complete the description of its life cycle. Periods of incubation, fertilization, planktonic stages, the attachment site on the fish host and biometric characteristics of larval forms were detailed. The new information may help better control health state of marine fish in aquaculture.
\end{abstract}

Keywords: Gnathiid isopods, aquarium, ectoparasite, harem formation, life history, infestation

In recent decades, interest in parasitic isopods of the family Gnathiidae has increased and their taxonomy has been revised (Cohen and Poore 1994, Smit and Davies 2004). Several new species have been described (Smit and Van As 2000, Smit and Basson 2002, Smit et al. 2002, Ota et al. 2007, Hadfield et al. 2008, Ota 2011) Moreover, ecological studies have been carried out on the role of isopod larvae in the food chain and their relationship with their corresponding hosts, including their pathological effects on wild and captive populations (Davies 1982, Mugridge and Stallybrass 1983, Drinan and Rodger 1990, Wagele 1992, Patarnello et al. 1995, Grutter and Hendrikz 1999, Heupel and Bennett 1999, Grutter et al. 2000, Davies and Smit 2001, Grutter 2003, Tanaka 2003, Marino et al. 2004, Genc 2007, Alas et al. 2009, Genc et al. 2011).

At present, the family Gnathiidae comprises 12 genera, including Gnathia Leach, 1813, which is the largest genus with over 190 species distributed worldwide (Cohen and Poore 1994, Hadfield and Smit 2008). Life cycles of only four species of gnathiids have been at least partly elucidated, namely those of G. africana (Barnard, 1914), G. maxillaris (Montagu, 1804), G. pilosus Hadfield, Smit et Avenant-Oldewage, 2008 and Caecognathia calva (Vanhöffen, 1914) (see Smith 1904, Wagele, 1988, Smit et al. 2003, Hadfield et al. 2009).

Gnathia maxillaris is one of the most studied species of the genus and its morphology was described by several authors (e.g. Smith 1904, Monod 1926, Cordillot 1979, Davies 1981). The species is widely distributed, having been found in the Atlantic Ocean and Baltic, North, Celt- ic, Mediterranean and Tyrrhenian Seas (Smit and Davies 2004), and its life cycle was studied by Smith (1904) and Mouchet (1928).

In early 1997, the Aquarium of Barcelona detected an infestation of fish with G. maxillaris in its biggest tank, the Oceanarium. This exhibition aquarium is the largest exhibition aquarium (approximately $3700 \mathrm{~m}^{3}$ ) of seawater, where over 3000 fish of 80 different species are kept (teleosts and elasmobranchs). The infestation was subsequently confirmed in other aquaria of the Mediterranean exhibition section. The autopsy of fish showed an extremely high number of parasites attached to the body and fins with fish morality (Hispano et al. 2013).

This study presents data on the life cycle of G. $\max$ illaris, which was carried out by sampling larvae from aquaria with large volumes of water and a high diversity of fish. The cycle was studied by monitoring the infestation for several years until G. maxillaris was eradicated from the aquaria. At the same time, a procedure was developed for cultivating and keeping $G$. maxillaris in the laboratory (mesocosms). This allowed a more detailed descriptive study of the different stages of this ectoparasite during its life cycle.

\section{MATERIALS AND METHODS}

\section{Sampling and counting of larvae in the Oceanarium and study of life cycle \\ Larvae were harvested in the Oceanarium using their posi- tive phototropism. The sampling was always performed at night (from $6 \mathrm{pm}$ to $9 \mathrm{am}$ ), by installing lights along the bottom of the}


Oceanarium outside the methacrylate walls. At the same time, water was pumped $\left(15 \mathrm{~m}^{3} / \mathrm{h}\right)$ to that point through a planktonic mesh of $200 \mu \mathrm{m}$ before returning to the Oceanarium as previously described (Hispano et al. 2013). Harvested larvae (zuphea and praniza forms) were rinsed with fresh water to immobilise them and thus facilitate their counting. Then, they were placed in a Petri dish (diameter of $90 \mathrm{~mm}$ ) and counted under a stereoscopic microscope. Individual parasites were quantified and classified as zuphea, praniza or adult.

\section{Identification of the parasite and its processing}

The ectoparasite was identified on the basis of morphological description of males by Monod (1926). A sampling method was developed based on multiple trays containing different substrates that were placed at the bottom of the Oceanarium (Hispano et al. 2013). Then, a photographic register was created using stereoscopic microscopy. Subsequently, some specimens were prepared for examination by scanning electron microscopy.

Briefly, samples of zuphea, praniza and adult forms were fixed with $10 \%$ formaldehyde solution. Then, samples were dehydrated with a graded ethanol series up to $100 \%$ ethanol. Samples were dried with the E3100 Jumbo Series II Critical Point Drier apparatus (Polaron, Watford, UK). Dehydrated samples were mounted and coated with gold using Sputtering (JEOL JFC 1100) coater, according to the manufacturer's instructions. Mounted samples were examined with a scanning electron microscope FEI Quanta 200 at the University of Barcelona's Scientific and Technical Services.

Maintenance and life cycle study of $G$. maxillaris in the laboratory (mesocosms)

The life cycle of G. maxillaris was also studied experimentally under laboratory conditions (mesocosms). Live harvested larvae from the Oceanarium or those obtained under laboratory conditions were kept in $100 \mathrm{ml}$ glass bottles with a screw cap at $18 \pm 0.5^{\circ} \mathrm{C}$. In preliminary tests, the conditions for keeping larvae were evaluated and the maximum maintenance temperature was established at $18 \pm 0.5^{\circ} \mathrm{C}$. Sampled larvae (zuphea or praniza) were kept individually to follow and record their development. The water was changed every two days. To keep a large number of individuals in the same laboratory mesocosm, bottles of larger volume were used.

\section{Attachment of larvae to fish hosts}

The study of the attachment of the parasites began with zuphea III larvae collected from the Oceanarium. First, zuphea III were tested on various species of teleosts as potential hosts, including sea bream (Sparus aurata Linnaeus), white sea bream (Diplodus sargus Linnaeus), saddle bream (Oblada melanura Linnaeus), giant goby (Gobius cobitis Pallas) and conger [Conger conger (Linnaeus)]. Finally, the transformation from zuphea III to praniza III was achieved using sedation and sea bream (S. aurata) as a fish host. Assays were performed using one fish and 20 zuphea III (approximately $3 \mathrm{~mm}$ ) in a 401 aquarium at room temperature.

The use of anaesthetics (clove oil, 12-20 ppm) was also evaluated to facilitate the attachment of the ectoparasite to the body of the host and to avoid predation of planktonic larvae by the fish host. Once the experimental conditions had been established, the area of attachment to the host and the length of the blood feeding period were recorded to determine any correlation between these factors. When any zuphea III sucked blood to pass to the praniza stage, it was subsequently removed from the tank and placed alone in a $100 \mathrm{ml}$ glass bottle with a loose screw cap at $18 \pm 0.5^{\circ} \mathrm{C}$. Then, each praniza was monitored for the next few days to observe changes to the adult phase.

\section{Study of larval stages}

The same experimental approach was also used to study the early stages of the cycle (from zuphea I to zuphea III). Different larval stages were obtained from sampling water of Oceanarium (Hispano et al. 2013). The biometric and morphological analyses were performed under a stereoscopic microscope. Average and standard deviation were calculated for all biometric parameters. Larvae were caught from the $100 \mathrm{ml}$ storage vessels with a $3 \mathrm{ml}$ plastic Pasteur pipette whose tip was cut to avoid damage to the larvae. The larvae were then placed in a Petri dish with a drop of seawater, and with the help of a punch were turned and then measured under the stereoscopic microscope using a micrometer. The length of the larval body (zuphea or praniza) was measured from the edge of the cephalosome (the position of the sucking device) to the end of the pleotelson. Males were measured from the edge of the jaws to the pleotelson. Females were measured from the tip of the cephalosome to the end of the pleotelson. Additionally, the evolution of larvae was tracked with a video camera and photography.

\section{Breeding assemblage study}

The forms involved in breeding were also detected under laboratory conditions. The aim was to determine whether the male could fertilize a praniza III just before it moulted to an adult female. The assay consisted of placing a male with one praniza III in seawater in a $100 \mathrm{ml}$ polypropylene vessel with a screw cap at $18 \pm 0.5^{\circ} \mathrm{C}$. The male was removed when the female praniza III began to moult. Fifteen assays using sets of an adult female with an adult male were kept in the same conditions. The adult females in these assays were from young praniza III, which were obtained in the laboratory from the zuphea III stage just after metamorphosis. Thus, we were certain that the recently moulted females had never been with a male. A photographic register and biometrics were also performed for all these assays. Praniza III and adult females from both sets of assays were tracked to observe their fertilization and then to describe their progress from embryogenesis to the hatching of zuphea I.

\section{RESULTS}

\section{Attachment of larvae to the fish host}

Zuphea forms can attach anywhere on the host's body. However, there is a preference for blood irrigated areas or protected parts of the body that make it difficult for the host to remove the parasite by surface friction. Areas such as the base of the fins, around the eyes and near the operculum promote rapid absorption of blood. As a result, parasites attach to these areas for shorter periods. The suction time (feeding period) was calculated from the attachment of zuphea to the host fish until its release (Table 1).

The feeding period was highly variable, ranging from 20 minutes to $2-3$ hours. Zuphea that were attached for short feeding periods with low blood ingestion had difficulties in further development and usually died before moulting. In contrast, zuphea with longer feeding periods ingesting significant amounts of blood showed greater ex- 
pansion of their bodies and succeeded to the next stages of the life cycle.

\section{Development of larval stages}

Zuphea I. The hatching period for zuphea I is between 48 and $72 \mathrm{~h}$ (Fig. 1A,B). Zuphea I were $1.00 \pm 0.08 \mathrm{~mm}$ long by $0.30 \pm 0.05 \mathrm{~mm}$ wide $(\mathrm{n}=25)$ (Fig. 1C). The number of zuphea per hatching varies depending on the size of the female from 30 to 90 . Zuphea I larvae hatched in the laboratory were used to study the attachment of this stage on sea bream (Sparus aurata) under experimental conditions described above. Though some zuphea attached to the host immediately, others were caught and eaten by fish very quickly.

Sedation could not be used at this stage, because the anaesthetics affected the larvae. Some zuphea I attached to the host and sucked it after hatching, especially when no yolk remained. Zuphea I still having yolk reserves of nutrients that help them survive for some time delayed for a few hours the attachment to the fish host. This first moult from zuphea I to praniza I could be considered similar to other transitions to praniza stages. Zuphea I always showed high activity, swimming energetically and positive phototropism.

Praniza I. Detached praniza I measured $2.6 \pm 0.2 \mathrm{~mm}$ in length by $0.6 \pm 0.1 \mathrm{~mm}$ in width $(\mathrm{n}=50)$. Praniza I were mostly caught in the Oceanarium monitoring. They needed at least 10 days to start the moult into zuphea II under laboratory conditions. The moulting process was a characteristic isopod moult, consisting of a posterior moult followed by an anterior moult. The anterior moult includes the cephalon and up to the third segment of the pereon. The posterior moult includes the rest of the pereon and the pleon (Fig. 1E). The whole moulting process takes approximately 24 hours. Praniza I larvae were also very active and usually swimming.

Zuphea II. The average length was $2.01 \pm 0.15 \mathrm{~mm}$ and width $0.6 \pm 0.1 \mathrm{~mm}(\mathrm{n}=55)$. The average increase in size with respect to zuphea I was around $1 \mathrm{~mm}$. Zuphea II showed a lag time of 10-15 days before they took food (blood sucking) by attachment to the host. These larvae were also very active, with positive phototropic swimming.

Praniza II. This larval stage measured $3.99 \pm 0.32 \mathrm{~mm}$ in length by $0.9 \pm 0.14 \mathrm{~mm}$ in width $(\mathrm{n}=50)$ (Fig. 1D). The increase in size and length with respect to praniza I was around $1.39 \mathrm{~mm}$. Praniza II showed less activity than the previous stages but were still usually swimming. The moulting process was similar to that observed for praniza I. It started in the posterior part of the body and finished in the anterior part. Praniza needed at least 10 days to start the moult into zuphea III under laboratory conditions.

The moulting period was very similar to that from praniza I to zuphea II, taking approximately 24 hours. In some cases, praniza II moulted into adult forms. In particular, a praniza II was observed directly moulting into a female $(3.3 \mathrm{~mm})$ and another to a male $(3.8 \mathrm{~mm})$. In
Table 1. Feeding period of zuphea (20 independent observations) and attachment site when blood was sucked from the fish host under laboratory conditions

\begin{tabular}{cc}
\hline Ingestion time (min) & Attachement place \\
\hline 21 & Head \\
25 & Head \\
25 & Head \\
27 & Dorsal fin \\
35 & Head \\
46 & Pectoral fins \\
59 & Head \\
61 & Pectoral fins \\
74 & Ventral fin \\
81 & Dorsal body \\
89 & Ventral fin \\
95 & Ventral fin \\
100 & Dorsal fin \\
102 & Dorsal fin \\
108 & Anus \\
111 & Dorsal fin \\
115 & Dorsal body \\
115 & Dorsal fin \\
115 & Dorsal fin \\
126 & Dorsal fin \\
&
\end{tabular}

the case of this specific female, the whole breeding period was monitored and a total of 33 viable zuphea I were hatched. This moult from praniza II to adult forms was observed several times under the experimental conditions in the laboratory.

Zuphea III. Over 400 zuphea III were observed and 50 of these were measured; they were $3.21 \pm 0.24 \mathrm{~mm}$ long by $0.9 \pm 0.1 \mathrm{~mm}$ wide (Fig. 2). Zuphea III were on average $1.20 \mathrm{~mm}$ longer than zuphea II. Zuphea III were also very active, swimming constantly. They showed positive phototropism.

Praniza III. A total of 279 praniza III were observed and they measured $5.19 \pm 0.38 \mathrm{~mm}$ in length by $1.54 \pm 0.25 \mathrm{~mm}$ in width $(\mathrm{n}=50$; Fig. $1 \mathrm{H})$. Praniza III were around $1.2 \mathrm{~mm}$ longer than praniza II. A decrease in activity was observed in this larval stage. It was possible to differentiate praniza III that would become males from those that would moult into females (Fig. 1F). This differentiation was possible, because the development of the ovary could be observed. In this study, we observed fertilization between an adult male and a future female praniza III (Fig. 1G).

This was first seen when a praniza III from the Oceanarium was isolated in the laboratory. After being kept alone, this praniza III completed the moult into female, hatched eggs and zuphea I emerged. This experience was confirmed experimentally 15 times using a container having an adult virgin female and a male. The eggs laid by these females were not viable. In contrast, when a similar experiment was performed with a future female praniza III and an adult male, mating occurred. The fertilized praniza III moulted into a female and laid viable eggs that hatched. 


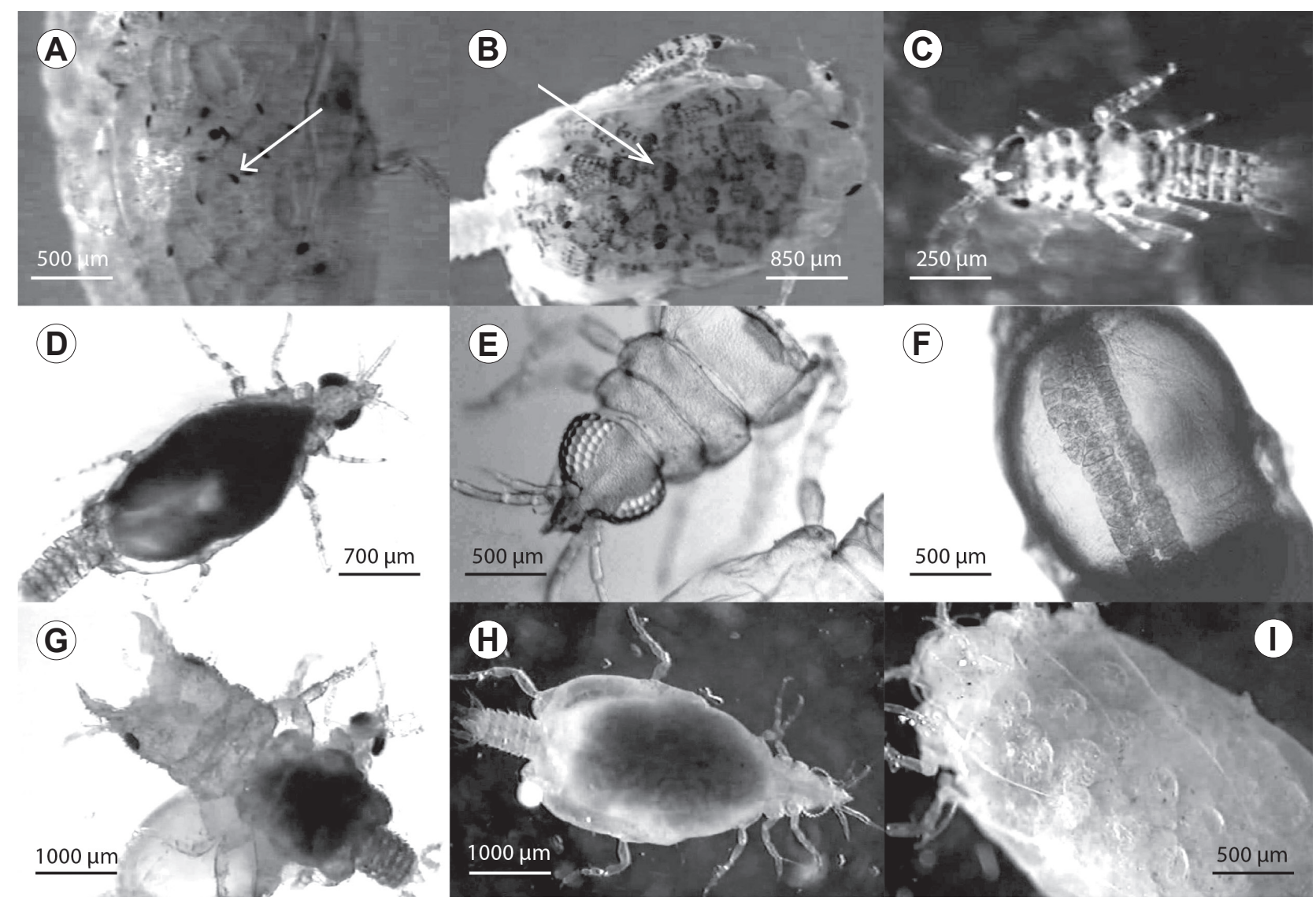

Fig. 1. Life cycle stages of Gnathia maxillaris. A - adult female hatching zuphea (arrow); B - adult female having zuphea (arrow); $\mathbf{C}$ - posthatched zuphea; D - praniza II; E - moults; $\mathbf{F}$ - developed gonads in praniza III; $\mathbf{G}$ - fertilization between female praniza III and adult male; $\mathbf{H}$ - first stage of praniza III moulting to adult female; I - female carrying embryonic eggs.

This observation was confirmed in 15 assays. The process of moulting from praniza III to adult forms was slower and took between 24 and 48 hours. Offspring were always obtained when metamorphosis and subsequent incubation of praniza III were successful.

Adults. Of a total of 258 praniza III, only 184 moulted into adult forms under laboratory conditions. Twentynine per cent mortality was recorded in the moulting process from praniza III to adult. The sex distribution after the moulting process was $56 \%$ males and $44 \%$ females. There was high synchronicity among the larval population in the moulting process from praniza III to the adult stage. Males require shorter moulting periods than females. Moulting of praniza III to males takes from 12 to 14 days, while praniza IIII moulting to females takes between 19 and 26 days, with an average of 22 days (Fig. 1E). A total of 35 males were measured. They had an average length of $5.20 \pm 0.72 \mathrm{~mm}$. Thirty females were also measured, with an average length of $4.70 \pm 0.68 \mathrm{~mm}$. Females showed an incubation period between 19 and 28 days (Fig. 1I). Hatching takes place between 48 and 72 hours. The average number of zuphea I per hatching and female was $51 \pm 20$ larvae. Females die within a few days of the birth of zuphea I. Males live about one to two months once they have moulted into adults.

\section{DISCUSSION}

Mouchet (1928) described the different larval stages of the life cycle of Gnathiidae based on observations of a group of individuals of Gnathia maxillaris. He described that larvae reached adult forms through progressive phases zuphea-praniza. Previously, other authors (Smith 1904, Monod 1923) recognized only three morphological stages in the cycle but not the larval phases: segmented free larvae, larvae attached to the host, and adult forms. These authors found a large difference in size between larvae of the same morphology, but have no explanation for such biometric diversity. Mouchet (1928) focused on explaining the diversity of sizes observed in each morphological larval type by Smith (1904) and Monod (1923). He did not study the adult phase, the period of incubation, or the size of larvae, nor other biometric values.

In the present study, adult phases have been studied and the period of attachment of larvae on the host has been monitored by determining the suction time (feeding period) and the attachment sites on the host. We also 


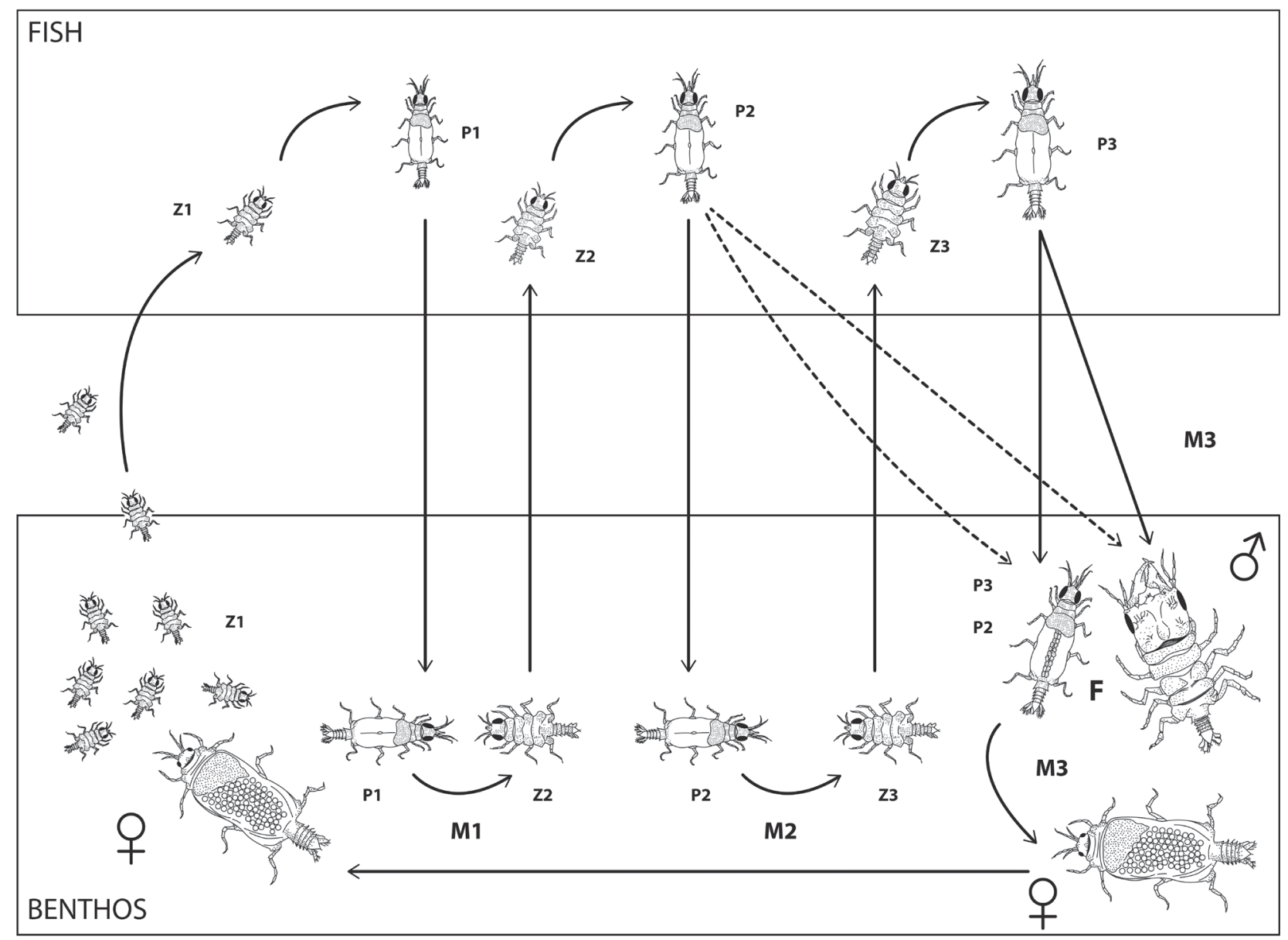

Fig. 2. Life cycle of Gnathia maxillaris. Abbreviations: P - praniza; Z - zuphea; F - fecundation; M1, M2 - moult; M3 - metamorphose.

measured all larval stages for the first time, using a representative sample of different stages and forms. Furthermore, we demonstrate the first metamorphoses between praniza I and II zuphea, which was supposed but not proved by Mouchet (1928).

The complementary approach (mesocosm and a large volume exhibition aquarium) used in this study enabled us to describe in detail the life cycle of $G$. maxillaris. Some aspects that could not be observed in the open sea or in the Oceanarium, such as metamorphosis and lifetime of males, were observed in the defined mesocosm.

It was observed that $G$. maxillaris in large aquaria followed the same pattern of activity throughout the day and emerged from the bottom to feed at night or at dusk or dawn. This pattern of activity has also been observed in nature for several isopods (Grutter 1999, Grutter and Hendrikz 1999, Grutter et al. 2000, Chambers and Sikkel 2002, Cote and Molloy 2003). The gregarious behaviour of larvae (both zuphea and praniza) and males was observed in vivo assays carried out. However, this behaviour was not as common in females.

The life cycle of $G$. maxillaris at a temperature of $17.5^{\circ} \mathrm{C}$ takes 3 months. When the temperature rose from
17.5 to $20^{\circ} \mathrm{C}$ in the Oceanarium, the duration of the cycle decreased to about two months. It was not possible to monitor the whole life cycle under laboratory conditions at higher temperature (room temperature around $22^{\circ} \mathrm{C}$ ), because of problems with the growth of ciliates and diatoms. The temperature increase also promoted growth of the parasite population, because females were larger and the number of eggs per female was higher. This temperature-linked relationship between the size of females and the number of eggs is in agreement with that reported by other authors for other isopod species (Klitgaard 1991, Tanaka and Aoki 2000).

Given the context of captivity and the environment in which this study was carried out, it cannot be said whether the cycle of $G$. maxillaris follows a seasonal pattern or not. A constant temperature was maintained in the aquarium with infected hosts and laboratory assays. The life cycle of another species, Gnathia africana, does not follow a seasonal pattern (Smit et al. 2003). This species occurs mainly on the coast of South Africa, which has a climate similar to the Mediterranean area where G. maxillaris lives. Other gnathiid species such as Paragnathia formica (Hesse, 1864) or Caecognathia calva exhibit seasonal 
patterns and their short life cycles have been attributed to the high temperature of water found in some seasons (Tanaka and Aoki 2000).

The use of anaesthetic for sedation of host fish was found to be essential to study the development of different larval stages in the laboratory. Otherwise, host fish caught planktonic larvae, especially during the stage of newborn zuphea. The sedation of host fish slowed down or stopped their predation of zuphea.

However, zuphea I were also affected by the anaesthetics. Therefore, we could follow the larval stages and their metamorphosis to adult stages that occurs during the life cycle of $G$. maxillaris. There are up to three moults in the life cycle: first moult of swollen larvae (praniza I) to segmented larvae (zuphea II), second moult of swollen praniza II to segmented zuphea III, and the last moult of praniza III to reproductive adult stages. We also observed that praniza II or praniza III could metamorphose to adult females.

Zuphea I newborns have a similar size to each other (about $1 \mathrm{~mm}$ in length). They are completely developed when they hatch and already show typical pigmentation. Soon after hatching, they can attach to the host. Zuphea I may still have yolk reserves, which are used during the first few days. Both observations confirmed previous studies (Monod 1926, Mouchet 1928, Smit et al. 2003).

It seems that $G$. maxillaris zuphea has no preference for any area of the host's body. However, zuphea that attaches to the fins need to suck blood longer and, subsequently, a longer period to change into praniza. This observation supports the suggestions of other authors (Smit et al. 2003), who assumed that the fins are less blood irrigated areas. Newborn zuphea I suck lymph and very few praniza I were found showing the pereon dilated with blood. This observation is in agreement with what other authors have indicated: when the mouthparts are smaller, the larvae cannot swallow blood cells (Grutter 2003).

It seems that this also depends on the position of feeding larvae on the fish and the extent of perforation and suction by the larva (Monod 1926). That is also why praniza II and III were sometimes found with a yellow or white hindgut contents. The green-blue colour of the hindgut of pranizas was also observed on those attached to Labrus bergylta (Ascanius) or Anguilla anguilla (Linnaeus), as described by other authors (Monod 1926, Mouchet 1928). Additionally, variation in the duration of the feeding period of zuphea could be related to zuphea size and the attachment area on fish. Swollen larvae detach from the host once they have ingested lymph or blood. Praniza I takes at least 10 days to moult into zuphea II.

Mouchet (1928) did not observe the moult to praniza II but he assumed that this moult exists. Zuphea II can still digest the food after finishing the whole moult. Then, zuphea II larvae could again attach to a host to continue the life cycle. However, in this study we observed that some praniza II can become adult under certain circumstances, while Mouchet (1928) observed only the moult from praniza III to adult forms.

The present study indicates that larvae from each stage are of a similar size, which differs from that of other larval stages and helps in recognition of larval forms. The sizes of $G$. maxillaris larvae in this study varied between $0.9 \mathrm{~mm}$ and $6.5 \mathrm{~mm}$, depending on the life cycle stage. Similar differences between larval stages have been reported in other gnathiids (Wagele 1988, Smit et al. 2003, Tanaka 2003).

The sex can be distinguished from praniza III. The transparency of the integument of the dorsal part of the body facilitates the monitoring of sexual differentiation and the development of eggs. It was observed that the width of the pereon in future female praniza increases as eggs are produced. The moult into adult starts after the maturation of the ovary.

Hesse (1864) suggested that fertilization occurs before moulting but did not provide any evidence. In this study, we confirmed that the fertilization occurs at this female praniza stage. This step differentiates $G$. maxillaris from other gnathiid species. For example, fertilization described for G. africana by Smit et al. (2003) and Caecognathia calva by Wagele (1987) occurs between female and male adults.

After a few days, eggs are laid in the female brood pouch (marsupium). Our observations indicate that embryogenesis progresses if the eggs are fertilized and lasts between 19 and 28 days. The hatching lasts 48-72 hours. Zuphea I leaving the marsupium through oostegites can easily be observed under stereoscopic microscope. Moreover, we observed that zuphea I have sometimes been observed re-entering the brood pouch. Additionally, in this study we saw that larvae of $G$. maxillaris do not moult after hatching before they become zuphea I, as observed for Gnathia piscivora Paperna et Por, 1977. The number of zuphea per hatching varies and is correlated with the size of the female, as also observed by other authors (Monod 1926, Tanaka and Aoki 2000).

When this stage starts from female praniza III zuphea I hatch, usually between 50 and 90 days. It has also been observed in the laboratory that what was thought to be praniza II can moult to adult forms (both males and females). The moult at this stage may be related to unfavourable environmental conditions or overlapping generations of males to increase the chances of mating. In such cases, the number of incubated eggs ranges between 20 and 40 and females die a few days after the zuphea have hatched.

The obtained results show that male praniza usually moult to adult males in a shorter period that females. Unlike the life cycle described for C. calva by Wagele (1987), praniza III of $G$. maxillaris moult directly to males. There was no stage of immature male as described for C. calva. 
Males G. maxillaris are usually larger than females. The size of their head and jaws makes them much longer than larval forms and adult females as also observed by Monod (1926). Our observation confirms data by Mouched (1928) that females die after hatching. Once males complete metamorphosis in laboratory conditions, they remained alive for 30 to 50 days.

The 'harem' behaviour of larvae was also observed in the laboratory and is similar to that seen in other species such as Paragnathia formica (Hesse, 1864), Caecognathia abyssorum (Sars, 1872), Caecognathia calva (Vanhöffen, 1914) and Caecognathia robusta (Sars, 1879) - see Upton (1987), Wagele (1988), Klitgaard (1991), Barthel and Brandt (1995). This behaviour was previously described by Monod (1926) and Mouchet (1928) in G. maxillaris. In this study we confirmed that this behaviour is usual in zuphea, praniza and males but was less common in fertilized adult females.
The moult from praniza to adult is very delicate and mortality is quite high. Results of the present study indicate that mortality rate reached approximately $30 \%$ under laboratory conditions. This is in agreement with data of other authors on the life cycle of other gnathiids such as G. africa-see Smit et al. (2003).

Knowledge of the behaviour and ecological characteristics of different ontogenetic stages of $G$. maxillaris enabled us to control the infestation of fish in the large aquarium and thus decrease and finally eradicate the parasite. Furthermore, the definition of a procedure to keep larvae in the laboratory was essential to carry out the assays presented in this study, which allowed a detailed observation of the life cycle stages.

Acknowledgements. We thank the University of Barcelona's Scientific and Technical Services for the support provided in the morphological study of Gnathia maxillaris forms.

\section{REFERENCES}

Alas A., Oktener A., Yilmaz M. 2009: Gnathia sp. (Gnathiidae) infestations on marine fish species from Turkey. Kafkas Univ. Vet. Fak. Dergisi 15: 201-204.

Barthel D., Brandt A. 1995: Caecognathia robusta (GO Sars, 1879) (Crustacea, Isopoda) in Geodia mesotriaena (Hentschel, 1929) (Demospongiae, Choristidae) at 75 degrees $N$ off $N E$ Greenland. Sarsia 80: 223-228.

Chambers S.D., Sikkel P.C. 2002: Diel emergence patterns of ecologically important, fish-parasitic, gnathiid isopod larvae on Caribbean coral reefs. Caribb. J. Sci. 38: 37-43.

Cohen B.F., Poore G.C. 1994: Phylogeny and biogeography of the Gnathiidae (Crustacea: Isopoda) with descriptions of new genera and species, most from south-eastern Australia. Mem. Mus. Victoria 54: 271-397.

Cordillot F. 1979: Anatomia de Gnathia maxillaris. Diplomarbeit in Zoologie, Institut für Zoologie der Universität Basel, 91 pp.

Cote I.M., Molloy P.P. 2003: Temporal variation in cleanerfish and client behaviour: does it reflect ectoparasite availability? Ethology 109: 487-499.

DAVIES A.J. 1981: A scanning electron-microscope study of the praniza larva of Gnathia maxillaris Montagu (Crustacea, Isopoda, Gnathiidae), with special reference to the mouthparts. J. Nat. Hist. 15: 545-554.

DAvies A.J. 1982: Further studies on Haemogregarina bigemina Laveran and Mesnil, the marine mish Blennius pholis L., and the isopod Gnathia maxillaris Montagu. J. Protozool. 29: 576583.

Davies A.J., Smit N.J. 2001: The life cycle of Haemogregarina bigemina (Adeleina: Haemogregarinidae) in South African hosts. Folia Parasitol. 48: 169-177.

Drinan E.M., Rodger H.D. 1990: An occurrence of Gnathia sp., ectoparasitic isopods, on caged Atlantic salmon. Bull. Eur. Assoc. Fish Pathol. 10: 141-142.

GENC E. 2007: Infestation status of gnathiid isopod juveniles parasitic on dusky grouper (Epinephelus marginatus) from the northeast Mediterranean Sea. Parasitol. Res. 101: 761-766.

Genc E., Oral M., Erol C. 2011: The evaluation of gnathiid (Crustacea: Isopoda: Gnathidae) parasitism in goldblotch grouper (Epinephelus costae Steindachner, 1878) in the north- eastern Mediterranean Sea using the self-organizing map (SOM). Parasitol. Res. 108: 1417-1424.

Grutter A.S. 1999: Infestation dynamics of gnathiid isopod juveniles parasitic on the coral-reef fish Hemigymnus melapterus (Labridae). Mar. Biol. 135: 545-552.

Grutter A.S. 2003: Feeding ecology of the fish ectoparasite Gnathia sp. (Crustacea: Isopoda) from the Great Barrier Reef, and its implications for fish cleaning behaviour. Mar. Ecol. Prog. Series 259: 295-302.

Grutter A.S., Hendrikz J. 1999: Diurnal variation in the abundance of juvenile parasitic gnathiid isopods on coral reef fish: implications for parasite-cleaner fish interactions. Coral Reefs 18: 187-191.

Grutter A.S., Lester R.J.G., Greenwood J. 2000: Emergence rates from the benthos of the parasitic juveniles of gnathiid isopods. Mar. Ecol. Prog. Series 207: 123-127.

Hadfield K.A., Smit, N.J. 2008. Description of a new gnathiid, Afrignathia multicavea gen. et sp. n. (Crustacea: Isopoda: Gnathiidae), from South Africa. Afr. Zool. 43: 81-89.

Hadfield K.A., Smit N.J., Avenant-Oldewage A. 2008: Gnathia pilosus sp. nov. (Crustacea, Isopoda, Gnathiidae) from the East Coast of South Africa. Zootaxa 23-41.

Hadfield K.A., Smit N.J., Avenant-Oldewage A. 2009: Life cycle of the temporary fish parasite, Gnathia pilosus (Crustacea: Isopoda: Gnathiidae) from the east coast of South Africa. J. Mar. Biol. Assoc. UK 89: 1331-1339.

Hispano C., Bultó P., Blanch A.R. 2013: Gnathia maxillaris infestation in exhibition aquaria: control and treatment strategies. J. Appl. Ichthyol. 29: 1139-1144.

Hesse M.R. 1864: Mémoire sur les pranizes et les ancées. Mém. Savant Étrangers. Acad. Sci. 18: 231-302.

Heupel M.R., Bennett M.B. 1999: The occurrence, distribution and pathology associated with gnathiid isopod larvae infecting the epaulette shark, Hemiscyllium ocellatum. Int. J. Parasitol. 29: 321-330.

KlitgaARD A.B. 1991: Gnathia abyssorum (GO Sars, 1872) (Crustacea, Isopoda) associated with sponges. Sarsia 76: 33-39.

Marino F., Giannetto S., Paradiso M.L., Bottari T., De Vico G., MACRi B. 2004: Tissue damage and haematophagia due to 
praniza larvae (Isopoda: Gnathiidae) in some aquarium seawater teleosts. Dis. Aquat. Org. 59: 43-47.

Monod T. 1926: A monograph of the Gnathiidae, including the morphology, biology and systematics of the group. Mem. Soc. Sci. Nat. Maroc. 13: 1-668.

Mouchet S. 1928: Note sur le cycle evolutif des Gnathiidae. Bull. Soc. Zool. France 53: 392-400.

Mugridge R.E.R., Stallybrass H.G. 1983: A mortality of eels, Anguilla anguilla L., attributed to Gnathiidae. J. Fish Dis. 6: 81-82.

Ота Y. 2011: A new species of the gnathiid isopod, Gnathia teruyukiae (Crustacea: Malacostraca), from Japan, parasitizing elasmobranch fish. Bull. Nat. Mus. Nat. Sci. Series A, Zool., Suppl. 5: 41-51.

Ota Y., Tanaka K., Hirose E. 2007: A new species of Gnathia (Isopoda: Cymothoida: Gnathidae) from Okinawajima island, Ryukyu archipelago, southwestern Japan. Zool. Sci. 24: 1266 1277.

Paperna I., Por F.D. 1977: Preliminary data on the Gnathiidae Isopoda of the northern Red Sea, the Bitter Lakes, Suez Canal, Egypt and the Eastern Mediterranean and the biology of Gnathia piscivora new species. Rapp. Proc. Verb. Reun. Comm. Int. Explor. Scient. Mer Medit., Monaco 24: 195-198.

Patarnello S.P., Fioravanti M.L., Caggiano M., Restani R. 1995: Infestazione da Gnathiidae (Crustacea, Isopoda) in $\mathrm{Pa}$ grus major. Boll. Soc. Ital. Patol. Ittic. 17: 32-36.

Smit N.J., Basson L. 2002: Gnathia pantherina sp. n. (Crustacea: Isopoda: Gnathiidae), a temporary ectoparasite of some elasmobranch species from southern Africa. Folia Parasitol. 49: 137-151

Received 14 May 2013
Smit N.J., Basson L., Van As J.G. 2003: Life cycle of the temporary fish parasite, Gnathia africana (Crustacea: Isopoda: Gnathiidae). Folia Parasitol. 50: 135-142.

Smit N.J., Davies A.J. 2004: The curious life-style of the parasitic stages of gnathiid isopods. Adv. Parasitol. 58: 289-391.

Smit N.J., Van As J.G. 2000: A new species, Gnathia nkulu sp. n. (Crustacea: Isopoda: Gnathiidae) from southern Africa. Folia Parasitol. 47: 235-240.

Smit N.J., Van As J.G., Basson L. 2002: Redescription of the female of Gnathia africana (Crustacea: Isopoda: Gnathiidae) from southern Africa. Folia Parasitol. 49: 67-72.

Sмітн G. 1904: Metamorphosis and life-history of Gnathia maxillaris (Isopoda). Mt. Stat. Neapol. 16: 469-479.

TANAKA K. 2003: Population dynamics of the sponge-dwelling gnathiid isopod Elaphognathia cornigera. J. Mar. Biol. Assoc. UK 83: 95-102.

Tanaka K., Aoki M. 2000: Seasonal traits of reproduction in a gnathiid isopod Elaphognathia cornigera (Nunomura, 1992). Zool. Sci. 17: 467-475.

Upton N.P.D. 1987: Asynchronous male and female life-cycles in the sexually dimorphic, harem-forming isopod Paragnathia formica (Crustacea, Isopoda). J. Zool. 212: 677-690.

WAGELE J.W. 1987: Description of the postembryonal stages of the Antarctic fish parasite Gnathia calva Vanhoffen (Crustacea, Isopoda) and synonymy with Heterognathia Amar and Roman. Polar Biol. 7: 77-92.

Wagele J.W. 1988: Aspects of the life-cycle of the Antarctic fish parasite Gnathia calva Vanhoffen (Crustacea, Isopoda). Polar Biol. 8: 287-291.

Wagele J.W. 1992: Antarctic Isopoda (Crustacea: Peracarida): stress in a polar environment? Bielefel. Ökol. Beitr. 6: 93-101.

Accepted 25 October 2013 